\title{
An automated micromethod for measuring iron concentration in serum using thioglycollic acid and bathophenantroline sulphonate
}

\author{
B. BROZOVIĆ AND YVONNE PURCELL
}

From the Department of Haematology, St Bartholomew's Hospital, London

SYNOPSIS An automated micromethod for measuring iron concentration in serum employing thioglycollic acid and bathophenantroline sulphonate as reducing agent and chromogen respectively, is described. Measurements are carried out using an AutoAnalyzer (Technicon) and require $0.1 \mathrm{ml}$ of sample. The reproducibility, assessed by the mean coefficient of variation $(1.9 \%)$, and the mean recovery of iron added to samples $(99.5 \%)$, as well as the correlation between the serum iron values estimated by the described method and the method recommended by the Expert Panel on Iron of the International Committee for Standardization in Haematology $(\mathrm{r}=0.9779 ; \mathrm{P}<0.001 ; y=$ $0.9713 x-0.0546$ ), is highly satisfactory. The method can also be used for measuring total ironbinding capacity of serum. The method appears equally suitable for routine work and research studies when a large number of samples and a small volume of serum are available.

The determination of serum iron concentration together with the estimation of 'total iron-binding capacity of serum (TIBC) is now a routine procedure in most hospital laboratories. There are more than 50 different methods for the determination of serum iron concentrations. Recently, the Expert Panel on Iron of the International Committee for Standardization in Haematology (ICSH) recommended the use of a method for measuring serum iron concentration which employs thioglycollic acid and bathophenantroline sulphonate as reducing agent and chromogen, respectively (ICSH, 1972). The ICSH found that these two reagents appeared superior to other reducing agents and chromogens tested. The ICSH stated that their method is primarily for use in standardization programmes but they also suggested that it can be used as a suitable clinical method for serum iron assay. Unfortunately, the recommended method, a hand method which requires $2 \mathrm{ml}$ of serum for analysis, cannot be used when a large number of samples are to be assayed and/or when a small volume of serum is available as in population surveys, paediatric work, and experimental work on small laboratory animals. Although several automated methods and micromethods for measuring

Received for publication 13 December 1973. iron concentration in serum have been described there is only one in which thioglycollic acid and bathophenantroline sulphonate are used (Giovanniello, DiBenedetto, Palmer, and Peters, 1968). The latter method requires $1.3 \mathrm{ml}$ of serum for analysis. If it were available, an automated micromethod employing thioglycollic acid and bathophenantroline sulphonate would seem to be the method of choice.

The purpose of this paper is to describe an automated micromethod for measuring serum iron concentration with thioglycollic acid and bathophenantroline sulphonate developed in accordance with the ICSH recommendations, and to compare it with the ICSH recommended method.

\section{Materials and Methods}

The determination of serum iron was carried out on sera from healthy persons and patients suffering from various diseases. Venous blood was taken from the subjects, using plastic syringes and placed in plain iron-free tubes (Luckham Ltd) or heparinized plastic tubes (Stayne Laboratories Ltd). After separation of serum or plasma, samples were assayed immediately or deep-frozen until the measurements were carried out. Comparative measurements on one sample were almost always made within a day. 


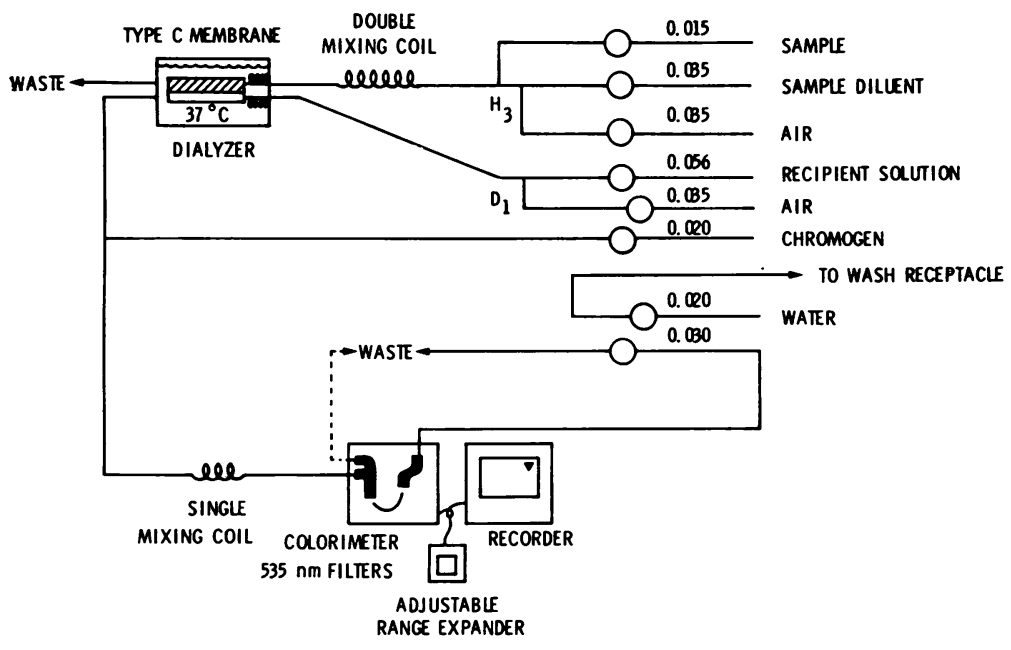

Fig 1 Manifold of the automated micromethod for measuring serum iron.
THE ICSH METHOD WITH THIOGLYCOLLIC ACID AND BATHOPHENANTROLINE SULPHONATE This was used in every detail as recommended by the ICSH (1972). Measurements were carried out using Unicam SP 600 spectrophotometer.

AUTOMATED MICROMETHOD WITH THIOGLYCOLLIC ACID AND BATHOPHENANTROLINE SULPHONATE

A Technicon AutoAnalyzer system, comprising sampler II, proportioning pump (two speed), single dialyzer, colorimeter fitted with a $15 \mathrm{~mm}$ tubular flow cell and $535 \mathrm{~nm}$ filters, and recorder with a range expander, was used. The manifold is illustrated in figure 1. Sample volume was $0.1 \mathrm{ml}$, sampling speed was 20 per hour, and sample to wash ratio was $1: 2$. This ratio obviated the use of water cups as spacers. Reagents were the sample diluent, (1 litre containing $1.5 \mathrm{ml}$ concentrated thioglycollic acid, 1 mole hydrochloric acid, and 0.5 mole sodium chloride), the recipient solution $(0.5 \mathrm{M}$ sodium acetate, $\mathrm{pH} 4 \cdot 65)$, and chromogen $(0.1 \mathrm{~g} / 1$ bathophenantroline sulphonate). Analytical grade reagents (Hopkin and Williams Ltd) were used with the exception of laboratory grade bathophenantroline sulphonate (BDH). Glassware rendered iron free by soaking overnight in $4 \mathrm{M} \mathrm{HCl}$ was used throughout. Polystyrene $0.5 \mathrm{ml}$ AutoAnalyzer cups (Technicon) were regarded iron free as received.

Iron standards, $44 \cdot 6,35 \cdot 7,22 \cdot 3,11 \cdot 2$, and 5.6 $\mu \mathrm{mol} / \mathrm{l}$, were prepared by dilution from the stock solution of $8.93 \mathrm{mM}$ ferrous ammonium sulphate in $10 \mathrm{mM}$ sulphuric acid. All five standards were measured at least four times in each batch.

\section{CALCULATION OF RESULTS}

The concentration of iron in samples was calculated from a calibration curve and the height of sample peaks by a programmed Olivetti P-203 calculator. A typical calibration curve is illustrated in figure 2 . The coefficient of correlation between serum iron values measured by the automated micromethod and the ICSH recommended method and the parameters of the regression line were calculated using the Olivetti programme no. 132 .

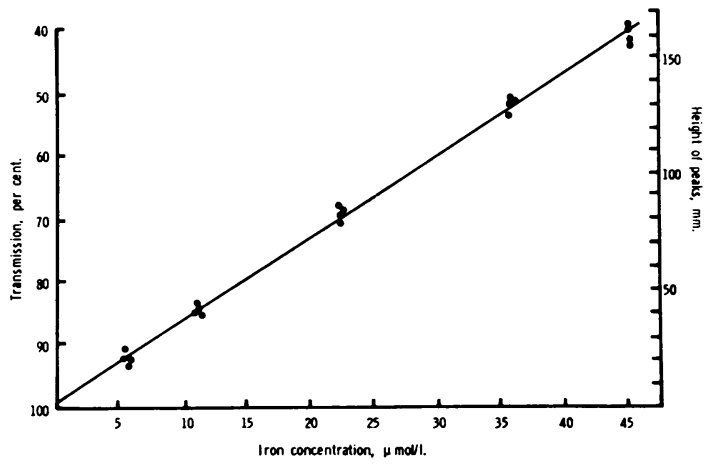

Fig 2 A typical calibration curve used for calibration of serum iron concentrations. In this batch of samples each of the iron standards was measured four times.

\section{Validation of the Micromethod}

The described automated micromethod for iron determination was evaluated first by estimating the 
reproducibility, and secondly by correlating the iron concentration values obtained using this method and the ICSH method. Reproducibility was assessed by measuring the coefficient of variation and recovery of added iron to serum, and by detecting possible carryover. The coefficients of variation for sera with iron concentration of $5.8,16.8$, and $40.5 \mu \mathrm{mol} / 1$ each analysed 10 times were $1.5,2.4$, and $1.8 \%$ respectively. The recovery of iron added to the serum was measured on five different samples in which the initial iron concentration ranged from 4.3 to $11 \cdot 1 \mu \mathrm{mol} / \mathrm{l}$. Iron concentration of samples before and after the addition of iron $(17.8 \mu \mathrm{mol} / \mathrm{l})$ was measured in quadruplicate and the mean difference, expressed as a percentage, represented recovery. The mean recovery was $99.5 \%$ (range from 95.7 to $104.4 \%$ ). No measurable carryover at a sampling speed of 20 per hour was detected either when samples with a low iron concentration (4.5 $\mu \mathrm{mol} / \mathrm{l})$ preceded or when they followed samples with a high concentration $(44.6 \mu \mathrm{mol} / \mathrm{l})$.

The correlation of serum iron values measured by the automated micromethod and the ICSH recommended method on 31 samples is illustrated in figure 3 and was found to be satisfactory $(r=0.9779$; $\mathrm{P}<0.001 ; y=0.9713 x-0.0546)$.

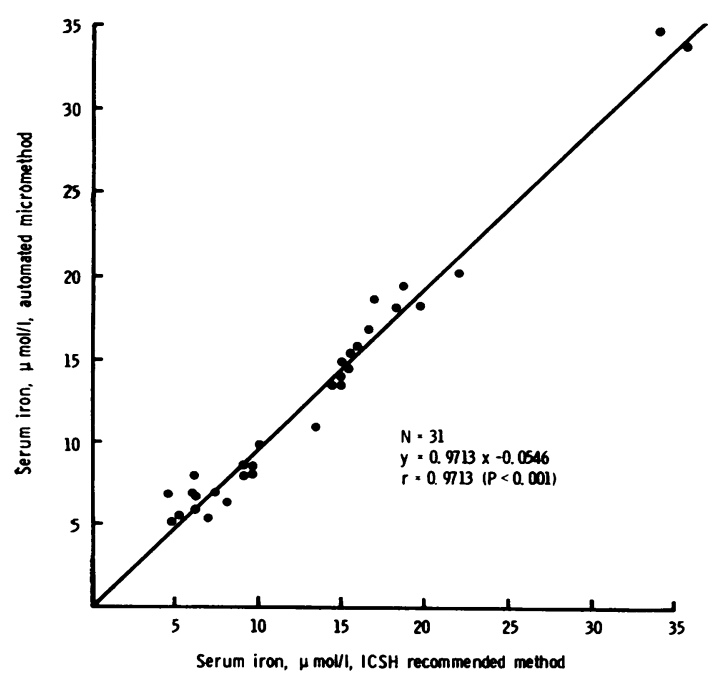

Fig 3 Correlation of serum iron values measured by the automated micromethod and the ICSH recommended method.

\section{Discussion}

The choice of thioglycollic acid as the reducing agent in the described automated micromethod for measuring serum iron concentration has been made in accord with the ICSH preference for it, although commonly used ascorbic acid is equally effective in extracting iron from transferrin below pH 6 and after five minutes of incubation (Giovanniello et al, 1968; Fielding and Ryall, 1970). However, a suggestion that interference from copper in serum is less pronounced with thioglycollic acid than with ascorbic acid (Giovanniello et al, 1968) justifies the ICSH preference for thioglycollic acid. Trichloracetic acid has been omitted from the sample diluent solution as the dialysis of samples obviates protein precipitation.

In the presented automated micromethod iron is dialyzed into the recipient buffer stream although i this is contrary to the generally accepted principle $N$ that the $\mathrm{pH}$ at both sides of the dialyzing membrane $\mathrm{O}$ should be roughly the same. In our laboratory it was consistently found that the height of the recorded peaks was decreased by one third when iron was dialyzed into a recipient stream of either water or bathophenantroline. The dialysis of iron into the $\vec{\theta}$ buffer stream has been previously described in $A$ several automated methods (Zak and Epstein, 1965; Garry and Owen, 1967; Kauppinen and Gref, 1967; Klein, Kleinman, and Searcy, 1970), but no explanation for doing so was offered. An attempt to simplify the manifold and dialyze iron into a stream containing both bathophenantroline and buffer (Kauppinen and Gref, 1967; Klein et al, 1970) was unsuccessful.

A range expansion factor of 10 was used most of the time, although a factor of 4 provided ample amplification for recording peaks of a satisfactory height. In our laboratory the amplification $\times 10$ proved free of trouble.

The reproducibility of the described automated micromethod as judged by the mean coefficient of variation $(1.9 \%)$ and the mean recovery $(99.5 \%)$ was comparable to the reproducibility reported for other automated methods (Kauppinen and Gref, 1967; 을 Giovanniello et al, 1968; Klein et al, 1970; Yee and Zin, 1971), and the ICSH recommended method of (ICSH, 1972). In addition there was a good correla- N tion between serum iron values measured by the described automated micromethod and the ICSH $O$ recommended method. It appears to be the first time that a statistical evaluation of serum iron values $\frac{2}{\oplus}$ measured by the ICSH method and by another method has been carried out. It is of particular 0 interest that the method used for the comparison was an automated one. The statistical evaluation indicated that the method described, and indeed other automated methods, can be used not only for routine measurements of serum iron concentration, 
but also for more delicate tasks in general research and those imposed by the ICSH programme for standardization of iron measurements.

In our laboratory the presented automated micromethod for measuring serum iron has been also used for measuring TIBC. After transferrin in serum samples is saturated with ferric chloride and the excess iron removed by magnesium carbonate (Ramsay, 1957), the procedure is the same as for measuring the iron concentration and does not require further comment.

It is a pleasure to thank Professor D. L. Mollin for valuable advice and encouragement and $\mathrm{Dr} J$. Fielding, St. Mary's Hospital, London, for suggesting the investigation on automation of the ICSH recommended method for iron measurements.

\section{References}

Fielding, J., and Ryall, R. (1970). The action of reducing agents on the dissociation of iron-transferrin with special reference to thioglycollate. Clin. chim. Acta, 28, 423-429.

Garry, P. J., and Owen, G. M. (1967). Automated micro determination $(100 \mu 1)$ of serum iron and total iron binding capacity. In Automation in Analytical Chemistry, p. 18. Technicon Corporation, New York.

Giovanniello, T. J., DiBenedetto, G., Palmer, D. W., and Peters, T., Jr. (1968). Fully and semi-automated methods for the determin-. ation of serum iron and total iron-binding capacity. J. Lab. clin. Med., 71, 874-883

International Committee for Standardization in Haematology: The Expert Panel on Iron (1972). Studies on the standardization of serum iron and iron-binding capacity assays. In Modern Concepts in Haematology, edited by G. Izak and S. M. Lewis, pp. 69-160. Academic Press, New York and London.

Kauppinen, V., and Gref, C. G. (1967). Automated determination of serum iron. Scand. J. clin. Lab. Invest., 20, 24-28.

Klein, B., Kleinman, N., and Searcey, R. L. (1970). Application of $\mathrm{Fe}^{+2}$-5-pyridyl benzodiazepin-2-ones to the automated determinations of serum iron and iron-binding capacity. Clin. Chem., 16, 495-499.

Ramsay, W. N. M. (1957). The determination of the total iron-binding capacity of serum. Clin. chim. Acta., 2, 221-226.

Yee, H. Y., and Zin, A. (1971). An AutoAnalyzer procedure for serum iron and total iron-binding capacity, with use of ferrozine. Clin. Chem., 17, 950-953.

Zak, B., and Epstein, E. (1965). Automated determination of serum iron. Clin. Chem., 11, 641-644. 